\title{
Getting serious about Canadian health research
}

$\mathrm{T}$ he imminent departure of Dr. Alan Bernstein from the presidency of the Canadian Institutes of Health Research (CIHR) will doubtless be the subject of much hand-wringing over a suitable replacement, future directions, programming and other structural matters at the nation's primary source of funding for academic health researchers.

Such issues and deliberations are valid, provided they are not allowed to cloud a more important debate and opportunity that change affords us: to redress the now-chronic shortage of funding. Underlying that need is the basic tenet that research is a fundamental public good: it makes a difference in terms of our understanding of disease and provides the highest quality evidence for patient care. It is also the engine for ingenuity and innovation in the health sector. It matters to everyone: taxpayers, parliamentarians and physicians.

In the scant 7 years since the CIHR was created from the ashes of the Medical Research Council of Canada and Bernstein was placed at its helm, the agency's budget has grown from about $\$ 250$ million per year to a current level of $\$ 828$ million, while its vision has extended beyond basic biomedical science to include the 3 other so-called pillars that CIHR now supports: clinical research, population health research, and health services and systems research.

Bernstein has done an admirable job of overseeing that transformation and growth, particularly in the face of the usual battery of factors and factions that invariably arise in the administration of research, including government's lack of appreciation of the importance of health research, internal squabbling in the research community about suitable division of the pie and pressures from end-users, such as businesses, health care administrators and the public. Compounding this was the short-sightedness of research stakeholders who did not see the need to spend monies on effective communication and other initiatives that would make research more justifiable or politically palatable - an essential first step toward helping others understand the importance of research and being accountable for tax dollars spent.

Negotiating those many perilous shoals was easier in CIHR's early days when its budget enjoyed double-digit annual increases. But it became more problematic as the increases tailed off. This lack of sustainable, long-term funding has prompted grumbling about the division of dollars among the 4 pillars, with basic biomedical scientists often leading the charge. In fact, $70 \%$ of all CIHR grants are now awarded for basic biomedical science, and it is researchers working within the other 3 pillars who have most cause for complaint about imbalance, particularly in light of the fact that it is their research that can deliver more immediate and comprehensive improvements in the health of Canadians.

Yet the solution is not to set up a competition among the pillars, which would be disastrous for Canadian science. All 4 pillars are justifiably clamouring for more money and the entire spectrum of researchers must be properly funded if the research enterprise is to maintain its own health.

For that to occur, the research community must first persuasively explain the rationale for and evidence of a need for increased funding. Canadian taxpayers have a right to know what their hard-earned dollars will buy and how it will improve their health or the state of the economy, or both.

Furthermore, the Canadian government needs to decide once and for all whether it is serious about being a meaningful global player in health research. To do so, it must vastly increase research outlays to the level provided by leading Organisation for Economic Co-operation and Development (OECD) nations. The United States, for example, will spend $\$ 28.9$ billion on academic health research in $2007,{ }^{1}$ or $\$ 95.37$ per capita. Canada will spend $\$ 828$ million, ${ }^{2}$ or $\$ 25.09$ per capita. If government is not interested in being a global player, then it should give up the charade. Canada's researchers, who have proven they can do more with less, are ill-served by short-term promises followed by long-term disappointments. If the funding won't be there, our best and brightest scientists should be told honestly to shop abroad for a stable platform on which to build the careers into which so much of their hard work and our tax dollars have been invested. The Canadian public should then be disabused of expectations that our health care problems will be addressed by made-inCanada solutions, reflecting Canadians' priorities and values.

\author{
Matthew B. Stanbrook MD PhD \\ Deputy Editor, Scientific, CMAJ \\ Paul C. Hébert MD MHSc \\ Editor-in-Chief, CMAJ \\ With the Editorial-Writing Team (Barbara Sibbald BJ, \\ Ken Flegel MDCM MSc, Noni MacDonald MD MSc \\ and Amir Attaran LLB PhD)
}

\section{REFERENCES}

I. Heinig SJ, Krakower JY, Dickler HB, et al. Sustaining the engine of US biomedical discovery. N Engl J Med 2007;357:I042-7.

2. Kondro W. International panel says CIHR needs management overhaul. CMAJ 2006; $175: 857$. 